\title{
Occurrence of Two High Molecular Phospholipases with Different Isoelectric Points in Porcine Pancreas and Their Reversible Interconversion
}

\author{
Hideyuki Matsuda and Osamu Hirayama \\ Department of Agricultural Chemistry, Shimane University, \\ Matsue 690, Japan \\ Received October 4, 1978
}

\begin{abstract}
Two high molecular weight proteins with phospholipase activity (Phospholipase-I and Phospholipase-II) were found to be present in the homogenate of porcine pancreas without delipidation and heat treatments. Phospholipase-I had an isoelectric point (pl) of about 4.5, while Phospholipase-II about 6.0. Both the Phospholipase-I and -II were purified by isoelectric focusing and gel filtration on Sephadex G-200. The molecular weights of both enzymes are about $5 \times 10^{5}$. Two enzymes differed greatly from each other in the heat stability and the effect of $\mathrm{pH}$ on the activities. Phospholipase-I (pI 4.5) was converted to the fraction with pI 6.0 by extraction of lipids, while Phospholipase-II (pI 6.0) to the fraction with pI 4.5 by addition of the extracted lipids in a yield of about $50 \%$. These converted enzymes were very similar to the corresponding native enzymes in the properties above described, respectively. These results suggest that the Phospholipase-I may exist as a Phospholipase-II-lipid complex. Furthermore, the relationship among the Phospholipase-I, Phospholipase-II, and the phospholipase $\mathrm{A}_{2}$ reported by de Haas $e t$ al. are discussed.
\end{abstract}

Pancreatic phospholipase A (EC 3.1.1.4) has been the subject of considerable research in the past. The enzymes of pancreatic tissues of porcine, ${ }^{1 \sim 6)} \mathrm{ox}^{7,8)}$ man, ${ }^{9,10)}$ horse, ${ }^{11)}$ and rat $^{12)}$ have been purified and characterized. Especially, porcine pancreatic phospholipase $\mathrm{A}_{2}$ was completely purified, ${ }^{(\sim 3)}$ and the enzymatic properties, ${ }^{1 \sim 3)}$ the primary structure, ${ }^{4,5)}$ and the active site $^{b /}$ of the purified enzyme were examined. Furthermore, it is known that phospholipases exist in pancreatic tissues as zymogens, which are converted to active enzymes via limited proteolysis by trypsin..$^{2,8,9,12)}$ Wezel and de Haas also reported that two phospholipase $A_{2}$ isoenzymes with isoelectric points of 6.3 and 5.9 exist in porcine pancreas in the ratio of about $95: 5$, respectively. ${ }^{13}$ ) However, almost all the purified phospholipases described above were extracted and isolated from the delipidated and heat-treated homogenate of porcine pancreas.

On the other hand, it is described that a high molecular weight lipase purified from human pancreas is converted to another low molecular weight lipase either by the extraction of endogeneous lipids with acetone or by digestion with phospholipase $A$, and the latter is converted to the former by adding pure bile, phosphatidylcholine, or phosphatidylserine but neither by lysophosphatidylcholine nor by sodium taurocholate. ${ }^{14)}$ From these observations it is speculated that the properties of the phospholipases of pancreas may be changed by the extraction of the lipids as well as heat treatment. However, with respect to porcine pancreas phospholipase, no such report has so far been published.

In the present study, the authors describe that two high molecular weight phospholipases with different isoelectric points, each of which differs significantly from the phospholipase $\mathrm{A}_{2}$ reported by de Haas et al., ${ }^{1,2)}$ exist in the homogenete of porcine pancreas without delipidation and heat treatments. Furthermore, it is reported that these two enzymes are purified by means of isoelectric focusing and gel filtration on Sephadex G-200, and are reversibly converted by the extraction or the addition of the endogeneous lipids. 


\section{MATERIALS AND METHODS}

Materials. Porcine pancreas was obtained from the local slaughterhouse, usually within $30 \mathrm{~min}$ after the death of the animal. The tissue, after being freed of most of the fat and connective tissue, was stored frozen at $-20^{\circ} \mathrm{C}$.

Reagents. Carrier ampholyte was obtained from LKB-Productor AB, Sweden. Sephadex G-200 and G-100 was purchased from Pharmacia Fine Chemicals $\mathrm{AB}$, Sweden. Sodium deoxycholate, ethylendiaminetetraacetic acid (EDTA), sodium dodecylsulfate, cetyltrimethylammonium chloride, $p$-chloromercuribenzoate, N-ethylmaleimide, cysteine, and mercaptoethanol were obtained from Wako Pure Chemical Industries Ltd., and diisopropylfluorophosphate from Kishida Chemicals Ltd. Pure reference proteins were purchased from Boehringer Mannheim, W. -Germany. All other reagents used were of analytical grade.

Substrates. Phosphatidylcholine was purified from egg lipids. ${ }^{15}$ ) Triglyceride was prepared from olive oil. ${ }^{16)}$

Enzyme assays. Phospholipase and lipase activities were assayed by determining free fatty acids released from a substrate, phosphatidylcholine or triglyceride, respectively, according to the method previously reported. ${ }^{17,19)}$ The substrate solutions used were now previously dispersed with sodium deoxycholate by ultrasonic treatments. The assay mixtures for phospholipase activity contained $0.5 \mathrm{~mm}$ phosphatidylcholine, $2 \mathrm{~mm}$ sodium deoxcholate, and $100 \mathrm{mM} \mathrm{CaCl}_{2}$ for phospholipase-I or $0.1 \mathrm{mM} \mathrm{CaCl}_{2}$ for phospholipase-II in $0.1 \mathrm{M}$ Tris- $\mathrm{HCl}$ buffer ( $\mathrm{pH} \mathrm{8.0)}$ ). The assay mixture for lipase contained $10 \mathrm{~mm}$ triglyceride, $2 \mathrm{~mm}$ sodium deoxycholate, and $10 \mathrm{~mm} \mathrm{CaCl}$ in $0.1 \mathrm{M}$ Tris-HCl buffer ( $\mathrm{pH} 7.0$ ). The mixtures (total volume, $1 \mathrm{ml}$ ) were incubated with shaking at $35^{\circ} \mathrm{C}$ for $20 \mathrm{~min}$. The enzyme activities were corrected by subtracting the rates of the enzymatic digestion of the endogeneous lipids contained in the enzyme preparations, which were obtained by the incubation without the substrates. The assay mixture for a low molecular weight phospholipase contained $0.5 \mathrm{~mm}$ phosphatidylcholine, $6 \mathrm{~mm}$ sodium deoxycholate, and $10 \mathrm{~mm} \mathrm{CaCl}_{2}$ in $0.1 \mathrm{M}$ Tris$\mathrm{HCl}$ buffer ( $\mathrm{pH} 8.0$ ). The enzyme activities were expressed as enzyme unit, where one unit of enzymes was defined as the amount of the enzyme which releases 1 $\mu \mathrm{mol}$ of free fatty acid from the substrate per min. The specific activities were expressed as the enzyme unit per mg of enzyme protein. Protein was determined by the Lowry method modified by Hartree. ${ }^{10}$ )

Isoelectric focusing. Isoelectric focusing was carried out in the $110 \mathrm{ml}$-apparatus of $\mathbf{L K B}$, using a carrier ampholyte (the $\mathrm{pH}$ range of $3 \sim 6$ ) at a final con- centration of $0.5 \%$ and a stepwise sucrose gradient $(0 \sim$ $50 \%)^{20}$ Electrophoresis was performed at $900 \mathrm{~V}$ for $48 \mathrm{hr}$ at $4^{\circ} \mathrm{C}$.

Gel filtration. A Sephadex G-200 column $(3 \times$ $20 \mathrm{~cm}$ ) equilibrated with $5 \mathrm{~mm}$ Tris- $\mathrm{HCl}$ buffer $(\mathrm{pH} 8.0)$ was used, and applied proteins were eluted with the same buffer.

Heat treatment. The enzyme preparation was heat-treated at $\mathrm{pH} 4.0$ and $100^{\circ} \mathrm{C}$ for 5 min according to the method described by de Haas et al. ${ }^{1)}$ The remaining activity was then assayed by the standard methods.

Extraction and addition of lipids. Five $\mathrm{ml}$ of the purified Phospholipase-I solution was added to 9 vol of acetone at $-50^{\circ} \mathrm{C}$. The mixture was centrifuged at $15,000 \times g$ for $30 \mathrm{~min}$. The precipitate was further treated with acetone and with diethyl ether at $-50^{\circ} \mathrm{C}$ by the same method. The resulting precipitate was immediately dried under vacuum at $0^{\circ} \mathrm{C}$ to remove the solvent. The delipidated enzyme was dissolved in the same volume of $5 \mathrm{~mm}$ Tris- $\mathrm{HCl}$ buffer ( $\mathrm{pH} 8.0$ ) (crude delipidated Phospholipase-I), and was subjected to isoelectric focusing. The extracted lipids were combined, dried by an evaporator, and dispersed in $5 \mathrm{ml}$ of the same buffer by ultrasonic tretment. The extracted lipid solution obtained was incubated with the purified delipidated Phospholipase-I obtained by isoelectric focusing or the purified Phospholipase-II at $4^{\circ} \mathrm{C}$ for $24 \mathrm{hr}$ (reconstituted Phospholipase-I or lipid-added Phospholipase-II, respectively).

Positional specificity. Positional specificity of a low molecular weight phospholipase was determined by the method as previously described. ${ }^{19}$ )

\section{RESULTS}

\section{Occurrence and purification of high molecular weight phospholipases}

Unless otherwise mentioned, all experiments were performed at about $4^{\circ} \mathrm{C}$.

Fresh porcine pancreas without delipidation were homogenized in $3 \mathrm{vol}(\mathrm{v} / \mathrm{v})$ of $10 \mathrm{~mm}$ Tris- $\mathrm{HCl}$ buffer ( $\mathrm{pH} 8.0$ ) in a Waring blender. The homogenate was filtered through two layers of nylon cloth. The filtrate was centrifuged at $15,000 \times g$ for $60 \mathrm{~min}$. The enzyme was further extracted from the pellet by the same method. The combined supernatant was concentrated by freeze-drying to give a crude extract. 


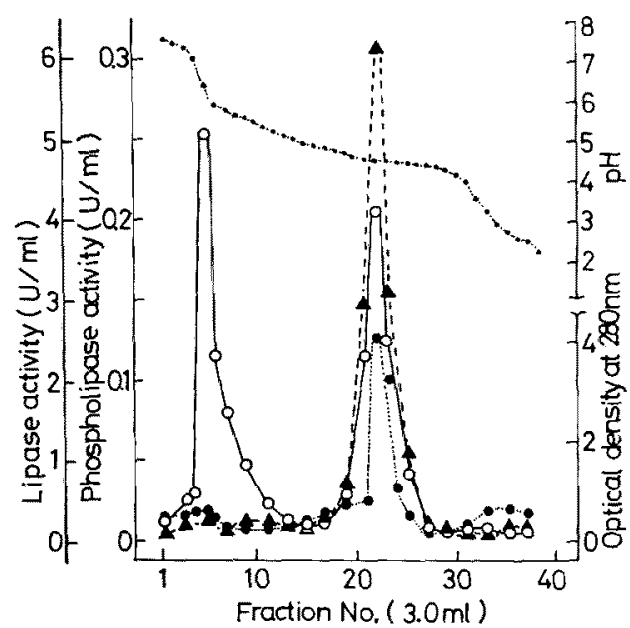

FIG. 1. Isoclectric Focusing of the Crude Extract. The crude extract obtained from the non-delipidated and non-heat-treated homogenate of porcine pancreas was subjected to isoelectric focusing. The isoelectric focusing was carried out for $48 \mathrm{hr}$ at $900 \mathrm{~V}$ and $4^{\circ} \mathrm{C}$ in a LKB 8101 column using ampholyte in the $\mathrm{pH}$ range of $3 \sim 6$ with the cathode at the bottom. After electrophoresis, the content of the column was fractionated into $3 \mathrm{ml}$ portions. Each fraction was

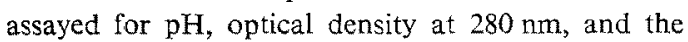
enzymic activities. ---. $\mathrm{pH}$; $-\bullet$, optical den-

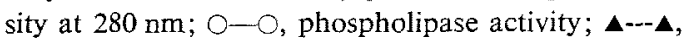
lipase activity.

The crude extract was subjected to electric focusing. As Fig. 1 shows, phospholipase activity was separated into two peaks with different isoelectric points of 4.5 (Phospholipase-I) and 6.0 (Phospholipase-II). The combined fractions of Nos. 19 25 (PhospholipaseI) and Nos. $4 \sim 8$ (Phospholipase-II) gave the yields of the enzyme activities of 47 and $44 \%$, respectively, of the total activity applied to the column. Almost all lipase activity, however, existed in the Phospholipase-I fraction.

Each of Phospholipase-I and PhospholipaseII obtained by isoelectric focusing was loaded on a Sephadex G-200 column $(3 \times 20 \mathrm{~cm})$ equilibrated with $5 \mathrm{~mm}$ Tris- $\mathrm{HCl}$ buffer $(\mathrm{pH}$ 8.0 ) containing $1 \mathrm{~mm}$ mercaptoethanol and $1 \mathrm{mM} \mathrm{CaCl}$ and was eluted with the same buffer. As is indicated in Fig. 2, both of the phospholipases were eluted after the void volume on the column, indicating that they had a similar high molecular weight. Lipase
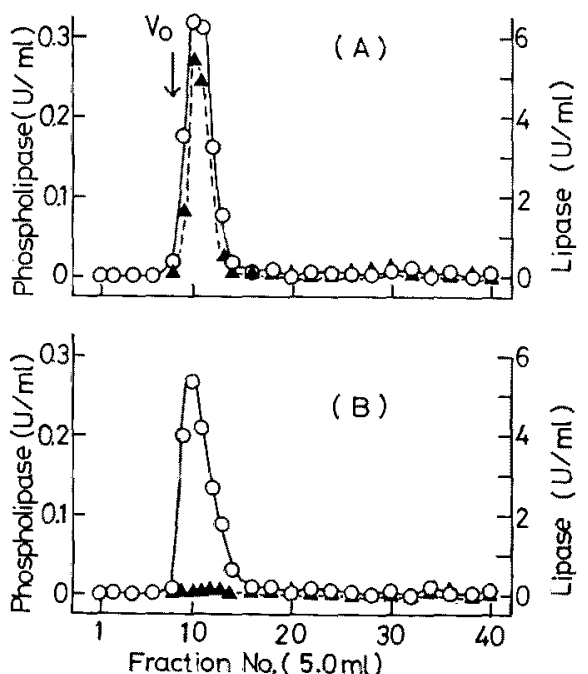

FIG. 2. Gel Filtrations of Phospholipase-I and -II on a Sephadex G-200 Column.

The Phospholipase-I and -II fractions obtained by isoelectric focusing were separately loaded on a Sephadex G-200 column $(3 \times 20 \mathrm{~cm})$ equilibrated with $5 \mathrm{~mm}$ Tris- $\mathrm{HCl}$ buffer ( $\mathrm{pH} \mathrm{8.0)}$ containing $1 \mathrm{~mm}$ mercaptoethanol and $1 \mathrm{mM} \mathrm{CaCl}_{2}$. Fractions of $5 \mathrm{ml}$ were collected and subjected to enzyme assay. A, Phospholipase-I fraction; B, Phospholipase-II fraction. $O-O$, Phospholipase activity; $\Delta-\cdots$, lipase activity.

Table I. Purifications of Phospholipase-I AND -II FROM NON-DELIPIDATED AND NON-HEATtreated Homogenate of Porcine Pancreas

\begin{tabular}{ccc}
\hline Stages & $\begin{array}{c}\text { Specific } \\
\text { activity } \\
\text { (mU/mg) }\end{array}$ & $\begin{array}{c}\text { Purification } \\
\text { (-fold) }\end{array}$ \\
\hline $\begin{array}{l}\text { Crude extract } \\
\text { Isoelectric focusing } \\
\text { Phospholipase-I }\end{array}$ & 2.85 & 1 \\
$\quad \begin{array}{l}\text { Phospholipase-II } \\
\text { Gel filtration on }\end{array}$ & 433.1 & 26 \\
$\quad$ Sephadex G-200 & & 152 \\
Phospholipase-I & 103 & \\
Phospholipase-II & 599 & 210 \\
\hline
\end{tabular}

activity, however, could not be separated from Phospholipase-I activity (Fig. 2A). The active fractions (fraction Nos. $9 \sim 15$ for both phospholipase-I and -II) were separately combined, concentrated by freeze-drying, and dialyzed against $5 \mathrm{mM}$ Tris- $\mathrm{HCl}$ buffer ( $\mathrm{pH} \mathrm{8.0)}$ for $12 \mathrm{hr}$. Phospholipase-I and Phospholipase-II were purified 36 - and 210 -folds, re- 
spectively, as summarized in Table I. The ratio of phospholipase activity to lipase activity in the partially purified Phospholipase-I fraction was $1: 10$. Phospholipase-II fraction contained no lipase activity.

\section{Properties of Phospholipase-I andPhospholipase- II}

Molecular weight. The molecular weight of each enzyme was determined by gel filtration on a Sephadex G-200 column according to the method of Andrews. ${ }^{21)}$ Both molecular weights were about $5 \times 10 .^{5}$

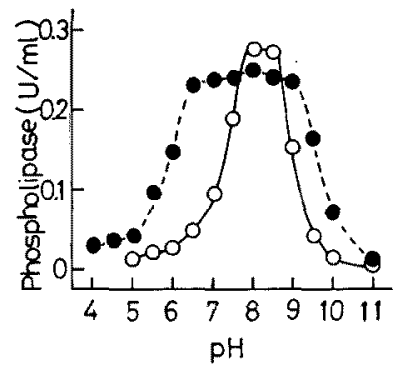

FIG. 3. Effect of pH on the Activities of Purified Porcine Pancreas Phospholipase-I and-II.

The enzyme activities were measured by the standard methods in $100 \mathrm{~mm}$ citrate buffer ( $\mathrm{pH} \mathrm{4.0 \sim 6.5),} 100$ $\mathrm{mm}$ Tris- $\mathrm{HCl}$ buffer (pH $7.0 \sim 9.0$ ), and $100 \mathrm{~mm}$ Sodjum carbonate buffer $(\mathrm{pH} 9.5 \sim 11)$. Phospholipase-I; O-O, Phospholipase-II.

Effect of $\mathrm{pH}$ on the activities. The $\mathrm{pH}$ dependent profiles of activities of both enzymes are shown in Fig. 3. Optimal pH for Phospholipase-II was in $\mathrm{pH}$ range of $8.0 \sim 8.5$, while that for Phospholipase-I spread over a broader $\mathrm{pH}$ range of $6.5 \sim 9.0$.

Heat stability. By heating at pH 4.0 and $100^{\circ} \mathrm{C}$ for $5 \mathrm{~min}$, Phospholipase-II lost $90 \%$ of its original activity, whereas PhospholipaseI retained more $95 \%$ of the activity. Even by heating for $10 \mathrm{~min}, 45 \%$ of the activity of Phospholipase-I remained. These results are demonstrated in Fig. 4. The extracted lipids $(0.2 \sim 1.2 \mathrm{mg})$ from Phospholipase-I and bovine serum albumin $(0.1 \mathrm{mg})$ protected considerably Phospholipase-II $(1.0 \mathrm{mg})$ from the inactivation by the heat treatment. However, they had no effect on the restoration of the enzyme inactivated.

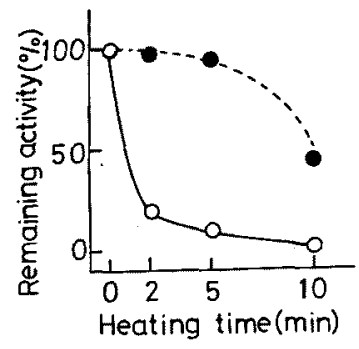

Fig. 4. Heat Stability of Porcine Pancreas Phospholipase-I and -II.

Each enzyme solution was brought to $\mathrm{pH} 4.0$ with $1 \mathrm{~N} \mathrm{HCl}$ and heated at $100^{\circ} \mathrm{C}$ for $5 \mathrm{~min}$. The solutions after being rapidly cooled to $0^{\circ} \mathrm{C}$, were freed from insoluble material by centrifugation and then subjected to enzyme assays. - - Phospholipase-I; $\bigcirc-\mathrm{O}$, Phospholipase-II.

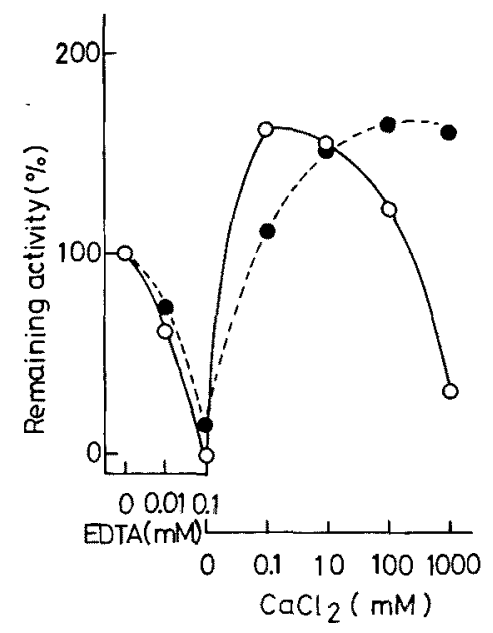

FIG. 5. Effects of $\mathrm{Ca}^{2+}$ and EDTA on Porcine Pancreas Phospholipase-I and Phospholipase-II.

The enzymes were preincubated with EDTA for $5 \mathrm{~min}$ at $0^{\circ} \mathrm{C}$ and then the remaining activities were assayed by the standard methods. Furthermore, the enzymes preincubated with $0.1 \mathrm{mM}$ EDTA were dialyzed against $5 \mathrm{~mm}$ Tris- $\mathrm{HCl}$ buffer ( $\mathrm{pH} 8.0$ ) for $12 \mathrm{hr}$, and then were assayed at various concentrations of $\mathrm{Ca}^{2+}$ by the standard methods. $\bullet--\bullet$, Phospholipase-I; $\mathrm{O}-\mathrm{O}$, Phospholipase-II.

Effects of $\mathrm{Ca}^{2+}$ and EDTA on phospholipase activities. As Fig. 5 shows, Phospholipase-I and $-\mathrm{II}$ exhibited progressive decreases of the activities with increasing the amount of EDTA added to the assay systems. Activities of both phospholipases were fully restored and enhaunced by $\mathrm{Ca}^{2+}$. Phospholipase-II activity was remarkably stimulated by $0.1 \mathrm{mM}$ 
Table II. Effects of Various Reagents on Porcine Pancreas Phospholipase-I and-II

\begin{tabular}{|c|c|c|c|c|}
\hline \multirow{2}{*}{ Reagents } & \multicolumn{2}{|c|}{ Conditions } & \multirow{2}{*}{ Phospholipase-I } & \multirow{2}{*}{ Phospholipase-II } \\
\hline & Conc. & $\mathrm{pH}$ & & \\
\hline \multirow{4}{*}{$\begin{array}{l}\text { None } \\
\text { Sodium dodecylsulfate }\end{array}$} & \multirow{2}{*}{\multicolumn{2}{|c|}{ - }} & \multicolumn{2}{|c|}{ Relative activity $(\%)$} \\
\hline & & & 100 & 100 \\
\hline & $0.01 \%$ & $\mathrm{pH} 8.0$ & 43 & 11 \\
\hline & $0.1 \%$ & $\mathrm{pH} \quad 8.0$ & 9 & 0 \\
\hline Cetyltrimethylammonium chloride & $0.1 \mathrm{~mm}$ & $\mathrm{pH} \quad 8.0$ & 24 & 0 \\
\hline$p$-Chloromercuribenzoate & $0.1 \mathrm{mM}$ & $\mathrm{pH} \quad 5.0$ & 50 & 87 \\
\hline N-Ethylmaleimide & $10 \mathrm{~mm}$ & $\mathrm{pH} 7.0$ & 65 & 65 \\
\hline Cysteine & $100 \mathrm{mM}$ & $\mathrm{pH} 8.0$ & 69 & 20 \\
\hline Mercaptoethanol & $100 \mathrm{mM}$ & $\mathrm{pH} 8.0$ & 52 & 13 \\
\hline Diisopropylffuorophosphate & $10 \mathrm{mM}$ & pH 8.0 & 103 & 91 \\
\hline
\end{tabular}

The enzymes were preincubated with each reagent for $20 \mathrm{~min}$ at $0^{\circ} \mathrm{C}$. After preincubation, the remaining activities were measured by the standard methods.

$\mathrm{CaCl}_{2}$ but inhibited by the cation at a higher concentration, while Phospholipase-I activity was markedly stimulated by the cation at a higher concentration (100 $\mathrm{mm}$ ).

Effects of detergents and reagents on both the activities. As Table II shows, both enzymes were strongly inhibited by detergents, sodium dodecylsulfate (anionic detergent) and cetyltrimethylammonium chloride (cationic detergent). Phospholipase-I was considerably inactivated by $p$-chloromercuribenzoate, $\mathrm{N}$ ethylmaleimide, cysteine, and mercaptoethanol, but was not inhibited by diisopropylfuorophosphate. Phospholipase-II was remarkably inactivated by cysteine and mercaptoethanol, but was not inhibited by disopropylfluorophosphate and p-chloromercuribenzoate. Phospholipase II was generally more sensitive than Phospholipase-I to the reagents.

\section{Reversible interconversion between Phospho- lipase-I and Phospholipase-II}

The delipidated Phospholipase-I and the reconstituted Phospholipase-I or the lipid-added Phospholipase-II were prepared as described in Materials and Methods. These treated enzymes and the native enzyme were separately subjected to isoelectric focusing. The results are summarized in Fig. 6. Almost all Phospholipase-I with an isoelectric point of 4.5 was shifted to the fractions corresponding to Phospholipase-II with an isoelectric point of 6.0 by the delipidation. Furthermore, the re- sulting delipidated Phospholipase-I and the native Phospholipase-II were converted to the fractions with an isoelectric point of 4.5 by

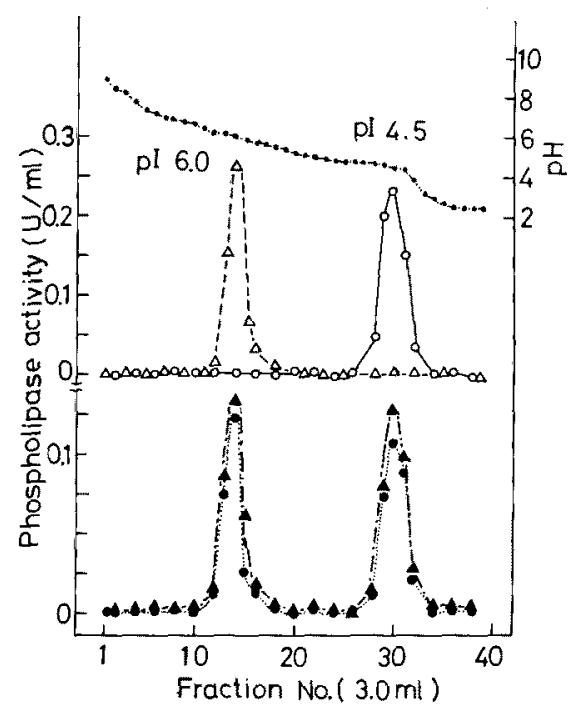

FIG. 6. Interconversions between Phospholipase-I and Phospholipase-II by Extraction and Addition of the Endogeneous Lipids.

Phospholipase-I preparation was delipidated as described in MATERIALS AND METHODS, and the resulting delipidated enzyme was applied to isoelectric focusing. Furthermore, the reconstituted Phospholipase-I and the lipid-added Phospholipase-II preparations prepared as described in MATERIALS AND METHoDs were also separately subjected to electrophoresis. Electric focusing was performed under the same conditions as described in Fig. 1. $\bigcirc-0$, Purified Phospholipase-I; $\triangle--\Delta$, delipidated Phospholipase-I; --- reconstituted Phospholipase-I; $\mathbf{A}-\boldsymbol{\Lambda}$, lipid-added Phospholipase-II; $\bullet \cdot \mathbf{0}, \mathrm{pH}$. 
addition of the extracted lipids in yields of about $50 \%$. Such shift of the isoelectric point was also observed when the crude extract of porcine pancreas was delipidated with the same method, as shown in Fig. 7. The delipidated

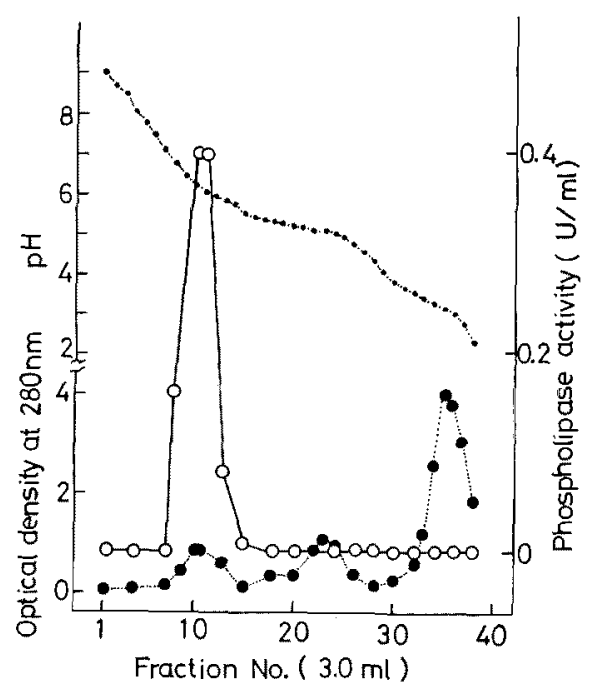

FIG. 7. Isoelectric Focusing of the Crude Extract of Delipidated Porcine Pancreas.

The crude extract obtained from the delipidated homogenate of porcine pancreas was subjected to isoelectric focusing. The isoelectric focusing was carried out under the same conditions as described in Fig. 1. $\mathrm{O}-\mathrm{O}$, Phospholipase activity, ---optical density at $280 \mathrm{~nm} ; \cdot \mathrm{pH}$. and the reconstituted enzymes did not contain lipase activity. Lipase activity in Phospholipase-I preparation was shifted to the fractions with an isoelectric point of 5.4 (Matsuda and Hirayama, unpublished data).

\section{Comparison of properties of the native and the converted phospholipases}

The properties of the native and the converted phospholipases are summarized in Table III. The delipidated Phospholipase-I and the purified reconstituted Phospholipase-I obtained in the experiment were very similar to native Phospholipase-II and native Phospholipase-I, respectively, in the properties such as isoelectric point, the behavior on gel filtration on Sephadex G-200, and heat stability. The lipid-added Phospholipase-II was also very similar to native Phospholipase-I.

\section{The composition of the extracted lipids}

The extracted lipids of Phospholipase-I were analyzed by the method previously dedescribed. ${ }^{23 ;}$ As demonstrated in Fig. 8 and Table IV, the extracted lipids consisted of free fatty acids, unknown lipids I and II, phospholipids, and other lipids. The unknown lipids and the effective components for the interconversion are not yet clear. They will be re-

Table III. Comparison of Properties of the Nattve and the Converted Phospholipases

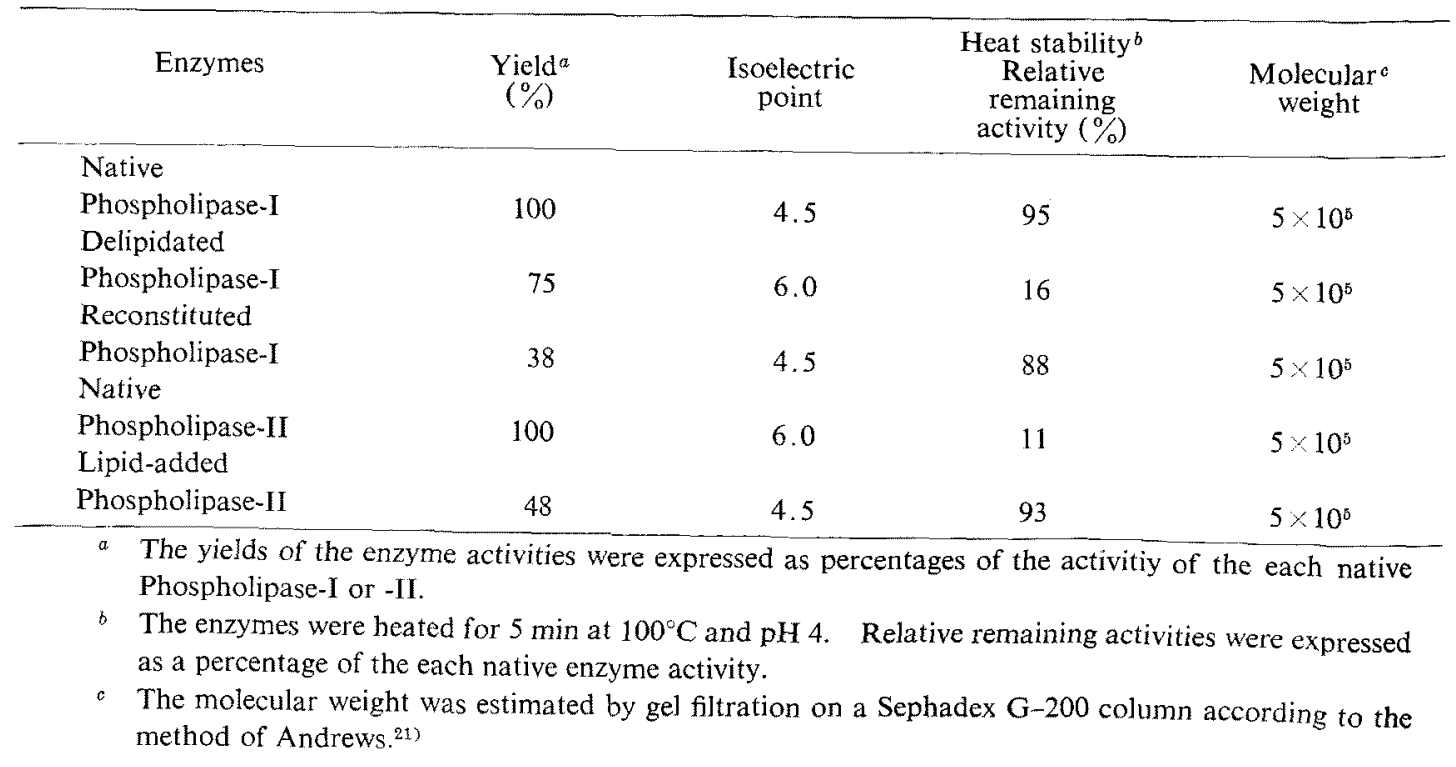




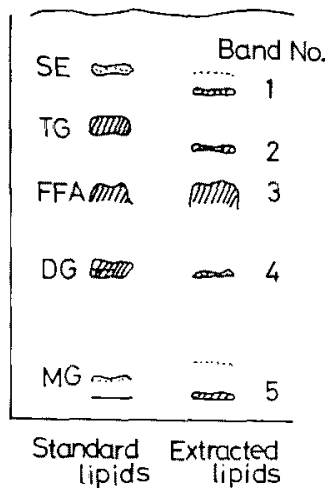

FIG. 8. Thin-layer Chromatogram of the Extracted Lipids.

The extracted lipids were developed on a silica gel plate with a solvent mixture, $n$-hexane/diethyl ether/ acetic acid $(80: 20: 1, \mathrm{v} / \mathrm{v})$. The lipids separated were detected with $50 \% \mathrm{H}_{2} \mathrm{SO}_{4}$ containing $1 \%$ dichromate. ${ }^{23)}$ Standard lipids: SE, sterol ester; TG, triglyceride; DG, diglyceride; MG, monoglyceride; FFA, free fatty acid. Numbers in figure show band number.

Table IV. Composition of the Extracted LIPIDS

\begin{tabular}{ccl}
\hline Band No. & Composition $(\%)$ & Lipids identified \\
\hline 1 & 23 & Unknown lipid I \\
2 & 14 & Unknown lipid II \\
3 & 41 & Free fatty acids \\
4 & 10 & diglyceride \\
5 & 7 & Polar lipids \\
(Phospholipids) \\
Others & 5 &
\end{tabular}

The composition of the extracted lipids was determined by the densitometry of the thin-layer chromatogram visualized by charring with $50 \% \mathrm{H}_{2} \mathrm{SO}_{4}$ containing $1 \%$ dichromate..$^{22}$

ported in near future.

Preparation of a low molecular weight phospholipase from Phospholipase-I

The purified Phospholipase-I was delipidated with acetone and diethyl ether as described in Materials and Methods. The precipitate was collected by centrifugation $(15,000 \times \mathrm{g}, 30 \mathrm{~min})$, and was dissolved in the small volume of $5 \mathrm{~mm}$ Tris- $\mathrm{HCl}$ buffer ( $\mathrm{pH} \mathrm{8.0)}$. The resulting enzyme solution was ajusted to pH 4.0 with $1 \mathrm{~N} \mathrm{HCl}$, and was heated at $100^{\circ} \mathrm{C}$ for $5 \mathrm{~min}$. After centrifugation $(10,000 \times g$,

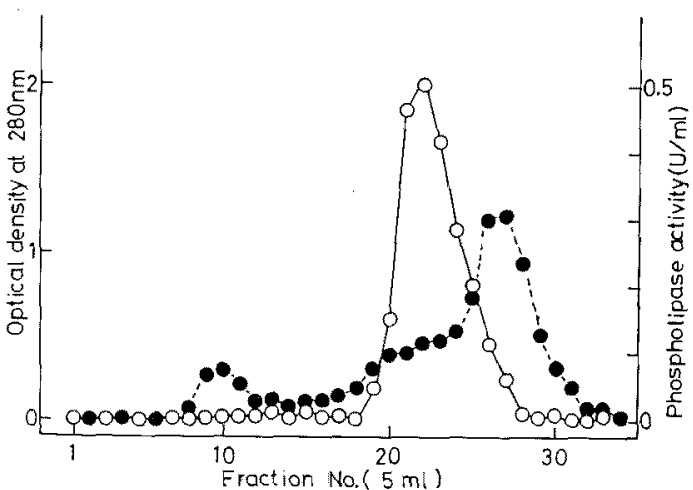

FIG. 9. Gel Filtration of Phospholipase Obtained from Phospholipase-I by Delipidation and Heat treatments on a Sephadex $\mathrm{G}-100$ Column.

The phospholipase obtained from Phospholipase-I by delipidation and heat-treatment was loaded on a Sephadex G-100 column $(3 \times 20 \mathrm{~cm})$ equilibrated with $5 \mathrm{~mm}$ Tris- $\mathrm{HCl}$ buffer $(\mathrm{pH} 8.0)$ containing $1 \mathrm{~mm}$ $\mathrm{CaCl}_{2}$, and eluted with the same buffer. Fractions of $5 \mathrm{ml}$ were collected and subjected to enzyme assay. 0 , Phospholipase activity; -...., optical density at $280 \mathrm{~nm}$.

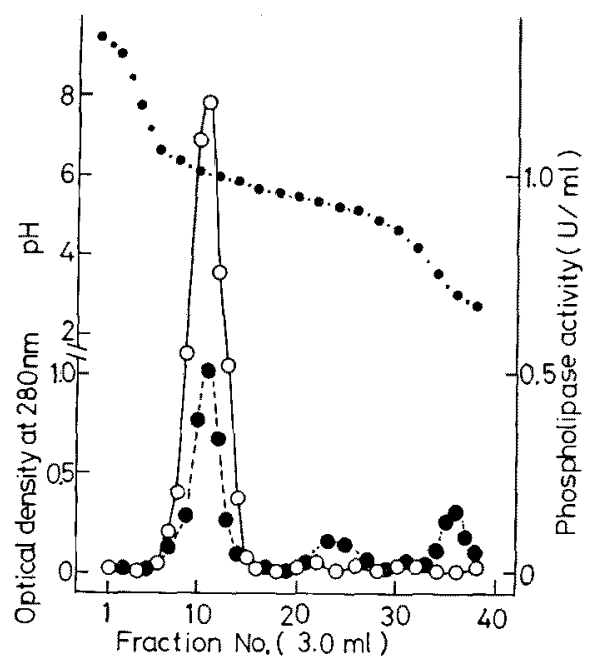

FIG. 10. Isoelectric Focusing of Low molecular Weight Phospholipase.

The low molecular weight phospholipase preparation obtained from gel filtration on Sephadex G-100 was subjected to isoelectric focusing using ampholyte in the $\mathrm{pH}$ range of $3 \sim 10$. The electrophoresis was performed under the same conditions as described in Fig. 1. $\bigcirc-0$, Phospholipase activity; ---o, optical density at $280 \mathrm{~nm} ; \cdot \mathrm{pH}$. 
Table V. Comparison of the Fatty Acid Compositions of Hydrolysis Products Obtained by a Low Molecular Weight Phospholipase and Snake Venom Phospholipase $A_{2}$ AS A REFERENCE ENZYME

\begin{tabular}{|c|c|c|c|c|c|c|c|}
\hline \multirow[t]{2}{*}{ Enzymes } & \multirow{2}{*}{$\begin{array}{l}\text { Hydrolysis } \\
\text { products }\end{array}$} & \multicolumn{6}{|c|}{ Fatty acids (mol $\%$ ) } \\
\hline & & $16: 0$ & $18: 0$ & $18: 1$ & $18: 2$ & Saturated & Unsaturated \\
\hline \multirow{2}{*}{$\begin{array}{l}\text { Snake venom } \\
\text { phospholipase } A_{2}\end{array}$} & $\mathrm{LPC}(\mathrm{C}-1)$ & 75 & 25 & trace & trace & 100 & trace \\
\hline & FFA (C-2) & 4 & 1 & 73 & 22 & 5 & 95 \\
\hline low molecular & $\operatorname{LPC}(\mathrm{C}-1)$ & 77 & 23 & trace & trace & 100 & trace \\
\hline $\begin{array}{l}\text { weight phospho- } \\
\text { lipase }\end{array}$ & FFA $(\mathrm{C}-2)$ & 5 & 2 & 71 & 22 & 7 & 93 \\
\hline
\end{tabular}

Egg phosphatidylcholine was hydrolyzed with a low molecular weight phospholipase and snake venom phospholipase $A_{2}$. Hydrolysis products were separated by thin-layer chromatography, and the resulting FFA and LPC-bound FFA were analyzed by gas chromatography as previously described. ${ }^{183}$ $\mathrm{C}-1$ and $\mathrm{C}-2$ show the positions of the lipid glycerol. LPC; lysophosphatidylcholine, FFA; free fatty acid.

$20 \mathrm{~min}$ ), the supernatant was dialyzed against $5 \mathrm{mM}$ Tris- $\mathrm{HCl}$ buffer ( $\mathrm{pH} 8.0$ ) for $12 \mathrm{hr}$. The dialyzate was loaded on a Sephadex G-100 column $(3 \times 20 \mathrm{~cm})$ equilibrated with $5 \mathrm{~mm}$ Tris- $\mathrm{HCl}$ buffer (pH 8.0) containing $1 \mathrm{~mm}$ $\mathrm{CaCl}_{2}$ and was eluted with the same buffer. As Fig. 9 shows, phospholipase activity was eluted as a single peak, indicating that it had a low molecular weight. The active fractions were collected and concentrated by freezedrying, and was subjected to electric focusing. As Fig. 10 indicates, the phospholipase had an isoelectric point of about 6.0. The active fractions were collected and dialyzed against $5 \mathrm{mM}$ Tris- $\mathrm{HCl}$ buffer ( $\mathrm{pH} 8.0$ ) for $12 \mathrm{hr}$ to give a purified low molecular weight phospholipase. The phospholipase was purified about 15 -fold from Phospholipase-I (536-fold from crude extract). The enzyme was estimated to be a molecular weight of about 14,000 by gel filtration on a Sephadex G-100 column, ${ }^{20}$ as shown in Fig. 11, and had also a high heat stability. Furthermore, the positional specificity of the enzyme was examined according to the method described previously. ${ }^{18}$ ) As Table $\mathrm{V}$ demonstrates, the fatty acid compositions of hydrolysis products such as free fatty acid and lysophosphatidylcholine by the phospholipase digestion were very similar to those of hydrolysis products by snake venom phospholipase $\mathrm{A}_{2}$ used as a reference enzyme. Therefore, the low molecular weight phospholipase seems to be an enzyme of $\mathrm{A}_{2}$ type. These properties

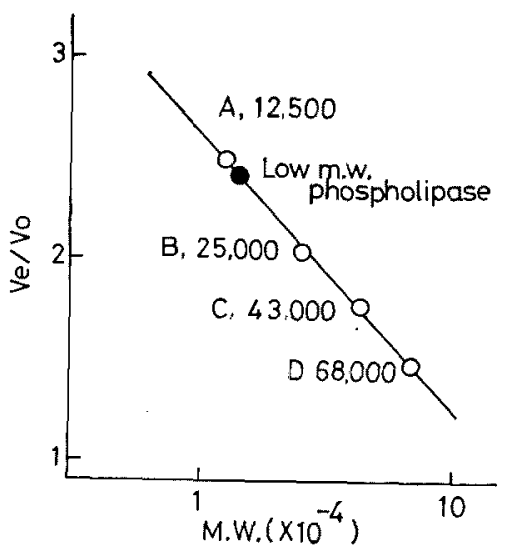

FIG. 11. Determination of the Molecular Weight of Phospholipase obtained from Phospholipase-I by Delipidation and Heat Treatments.

The purified phospholipase was loaded on a Sephadex G-100 column $(0.9 \times 22 \mathrm{~cm})$ equilibrated with $5 \mathrm{~mm}$ Tris- $\mathrm{HCl}$ buffer ( $\mathrm{pH} 8.0$ ) containing $1 \mathrm{~mm} \mathrm{NaCl}$, and eluted with the same buffer. ${ }^{20)}$ The fractions of 0.5 $\mathrm{ml}$ were collected. The reference proteins were filtrated under the same condition. A, Cytochrome C $(\mathrm{M} . \mathrm{W} .=12,500)$; B, chymotrypsinogen (M. W. = $25,000) ; C$, ovalbumin (M. W. $=43,000) ; D$, serum albumin (M. W. $=68,000)$.

were in agreement with those of porine pancreas phospholipase $A_{2}$ described by de Haas et al., ${ }^{1,2)}$ and van Wezel and de Haas, ${ }^{13)}$ as shown in Table VI.

\section{Relationship among Phospholipase-I, Phospho-} lipase-II, and low molecular weight phospholipase $\mathrm{A}_{2}$

Relationship among these three phospholi. 


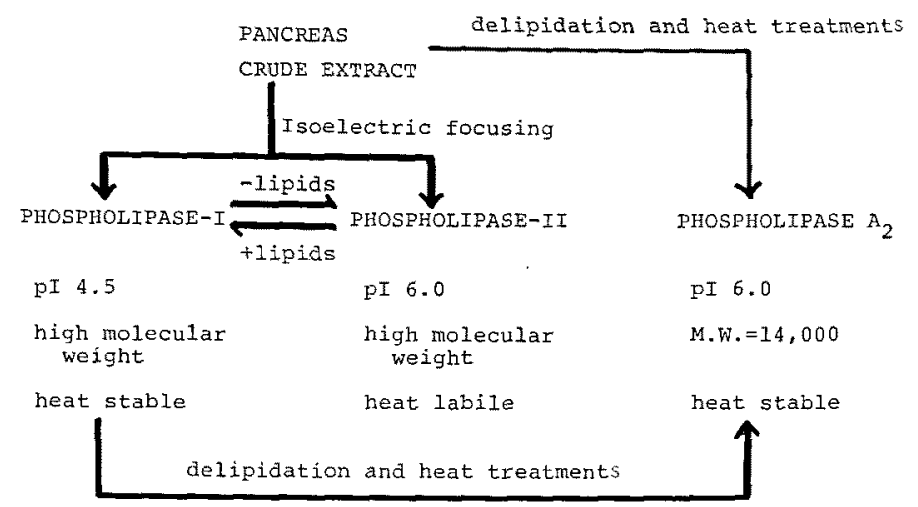

Fig. 12. Relationship Among High Molecular Weight Phospholipase-I and Phospholipase-II, and Low molecular Weight Phospholipase $\mathrm{A}_{2}$.

$\Rightarrow$, Route in this experiment; $\rightarrow$, Route reported by de Haas et al. ${ }^{1,2)}$

Table VI. Comparison of Properties of Low Molecular Weight Phospholipase with PhSOPHOLIPASE $\mathrm{A}_{2}$

\begin{tabular}{lcc} 
& $\begin{array}{c}\text { Low } \\
\text { molecular } \\
\text { weight } \\
\text { phospholipase }\end{array}$ & $\begin{array}{c}\text { Phospholipase } \\
\mathrm{A}_{2} a\end{array}$ \\
\hline $\begin{array}{l}\text { Optimum pH } \\
\text { Molecular weight }\end{array}$ & 8.0 & 8.0 \\
Isoelectric point & 14,000 & $14,000^{3}$ \\
Heat stability & about 6.0 & 6.3 \\
Positional & stable & stable \\
specificity & $\mathrm{A}_{2}$ type & $\mathrm{A}_{2}$ \\
\hline
\end{tabular}

a From de Haas et $a l .,{ }^{1,2)}$ and van Wezel and de Hass. ${ }^{13)}$

$b$ By gel filtration on Sephadex G-7513).

pases may be illustrated in Fig. 12 from the results described above. Fresh porcine pancreas contained two high molecular weight phospholipases, and these phospholipases seem to be reversibly converted to each other by delipidation or by incubating it with the extracted lipids. Low molecular weight phospholipase $A_{2}$ was obtained from high molecular weight phospholipase-I by delipidation and heat treatments.

\section{DISCUSSION}

Two high molecular weight Phospholipase-I and Phospholipase-II with different isoelectric points of 4.5 and 6.0 , respectively, were found in the homogenate without delipidation and heat treatments of porcine pancreas (Fig. 1).
Phospholipase-I was converted to the fractions corresponding to Phospholipase-II by delipidation, while Phospholipase-II was converted to the fractions corresponding to Phospholipase-I by incubating it with the extracted lipids. Furthermore, a low molecular weight phospholipase was obtained from the Phospholipase-I by delipidation and heat treatments. The enzyme obtained was very similar to phospholipase $A_{2}$ purified from porcine pancreas with delipidation and heat treatments. ${ }^{1,2)}$ These results suggested that Phospholipase-I exist as a lipoprotein which is composed of Phospholipase-II and unknown lipids. The proteins of both phsopholipases may be the same. Furthermore, the two high molecular weight phospholipases seem to be in more native and physiological forms than low moecular weight phospholipase in the pancreas.

It is known that all the lipases obtained from human pancreas, ${ }^{14,23)}$ human adipose tissue, ${ }^{243}$ and rat liver ${ }^{25}$ exist as a protein-lipid complex. Erlanson et al., ${ }^{23)}$ reported that human pancreatic lipase forms macromolecular aggregates in intestinal content. Furthermore, Kimura et al., ${ }^{14}$ described that a high molecular weight Lipase-F exists as a low molecular weight Lipase-S-phosphatidylcholine complex, and they further suggested that Lipase-S is synthesized in the human pancreas and secreted to the pancreatic duct, and then 
is modified in the duodenum in the presence of bile to form Lipase-F. Since the porcine pancreas phospholipases changed the isoelectric point by the extraction or addition of endogeneous lipids, they differed from the human pancreatic lipase ${ }^{14}$ and adipose tissue lipase, ${ }^{24)}$ which showed a change in molecular weights. Although the physiological roles of Phospholipase-I and -II are not clear, the greater stabilities of Phospholipase-I against heat-denaturation (Fig. 4) seem to have a physiological importance. Furthermore, much broader optical pH of Phospholipase-I (Fig. 3) may give a better property to the enzyme for working in intestinal content. The physiological importance of the modification of the enzyme by lipids also should be emphasized. ${ }^{25}$,

Almost all Phospholipase-I was converted to the fractions corresponding to Phospholipase-II by delipidation, but only about $50 \%$ of Phospholipase-II was converted to the fractions corresponding to Phospholipase-I by incubating it with the extracted lipids (Fig. 6 and Table III). The yield of the conversion might be increased more than $50 \%$ under more suitable conditions. However, since Phospholipase-I and -II were usually found at the ratio of about $1: 1$ in the crude extract, it seems likely that a equilibrium is established for the conversion under the conditions tested.

Human pancreatic Lipase-S was converted to Lipase-F by incubating with pure bile, phosphatidylcholine, or phosphatidylserine, but neither with lysophosphatidylcholine nor with sodium taurocholate. ${ }^{14}$ Effective components required for the conversion of porcine pancreas phospholipases are not yet clear. However, there may be a possibility that the effective components are anionic substances, e. g., anionic phospholipids, because the isoelectric point of Phospholipase-II shifted to more acidic $\mathrm{pH}$ by addition of the extracted lipids.

De Haas et al., also reported that the highly purified pancreatic lipase has a strong lipase activity and a slight phospholipase $\mathrm{A}_{1}$ activity. ${ }^{26}$ As Figs. 1 and 2 show, Phospholipase-
I fractions contained a high activity of lipase (the ratio of the activity of phospholipase to that of lipase is about $1: 10$ ). However, the lipase in the Phospholipase-I fractions (isoelectric point of 4.5) was converted to other fractions with an isoelectric point of 5.4 by extracting lipids with acetone and diethyl ether (Matsuda and Hirayama, unpublished data). Native Phospholipase-II and reconstituted Phospholipase-I preparations contained no lipase activity. Therefore, it seems that the phospholipase $A_{1}$ activity of the purified lipase is independent of the conversion in this experiment.

The modification of the enzyme by the endogeneous lipids is of physiological importance, ${ }^{14,25)}$ and the further properties and structures of such phospholipases are very interesting. The substrate and positional specificities, the mode of action, and the subunit structure of the phospholipases will be reported in near future.

Acknowledgment. This work was supported in part by a Scientific Research Grant from the Ministry of Education of Japan.

\section{REFERENCES}

1) G. H. de Haas, N. M. Postema, W. Nieuwenhuizen and L. L. M. van Deenen, Biochim. Biophys. Acta, 159, 103 (1968).

2) G. H. de Haas, N. M. Postema, W. Nieuwenhuizen and L.L.M. van Deenen, ibid., 159, 118 (1968).

3) W. Nieuwenhuizen, P. Steenberch and G. H. de Haas, Eur. J. Biochem., 40, 1 (1973).

4) G. H. de Haas, A. J. Slotboom, P. P. M. Bonsen and L. L. M. van Deenen, Biochim. Biophys. Acta, 221, 31 (1970).

5) G. H. de Haas, A. J. Slotboom, P. P. M. Bonsen, W. Nieuwenhuizen, L. L. M. van Deenen, S. Moroux, V. Dlouha and P. Desnuelle, ibid., 221, 54 (1970).

6) J. J. Volwerk, W. A. Pieterson and G. H. de Haas, Biochemistry, 13, 1446 (1974).

7) A. Rimon and B. Shapiro, Biochem. J., 71, 620 (1959).

8) C. E. Dutilh, P. J. van Doren, F. E. A. M. Verheul and G. H. de Haas, Eur. J. Biochem., 53, 91 (1975).

9) C. Figarella, F. Clemente and O. Guy, Biochim. Biophys. Acta, 227, 213 (1971).

10) W. L. Magee, J. Gallai-Hatchard, H. Saunders 
and R. H. S. Thompson, Biochem. J. 83, 17 (1962).

11) H. van den Bosch, N. M. Postema, G. H. de Haas and L. L. M. van Deenen, Biochim. Biophys. Acta, 98, 657 (1965).

12) B. Arnesjo, J. Barrowman and B. Borgstrom, Acta Chem. Scand., 21, 2897 (1967).

13) F. M. van Wezel and G. H. de Haas, Biochim. Biophys. Acta, 410, 299 (1975).

14) H. Kimura, T. Kitamura and M. Tsuji, ibid., 270, 307 (1972).

15) M. C. Pangborn, J. Biol. Chem., 188, 471 (1951).

16) K. K. Carroll and B. Serdarevich, "Lipid Chromatographic Analysis" vol. 1, ed. by G. V. Marinetti, Dekker, Inc., New York, 1967, p. 205.

17) O. Hirayama and H. Matsuda, Agric. Biol. Chem., 36, 1831 (1972).
18) H. Matsuda and O. Hirayama, Nippon Nōgeikagaku Kaishi, 49, 577 (1975).

19) E. F. Hartree, Anal. Biochem., 48, 422 (1972).

20) O. Hirayama, H. Matsuda, H. Takeda, K. Maenaka and $\mathrm{H}$. Takatsuka, Biochim. Biophys. Acta, 384, 127 (1975).

21) P. Andrews, Biochem. J., 96, 595 (1965).

22) O. Hirayama and H. Matsuda, Agric. Biol. Chem., 36, 2593 (1972).

23) C. Erlanson and B. Borgstrom, Scand. J. Gastroent., 5, 395 (1970).

24) J. D. Schnatz and J. A. Cortner, J. Biol. Chem., 242, 3850 (1967).

25) H. Okuda and S. Fujii, J. Biochem., 64, 377 (1968).

26) G. H. de Haas, L. Sarda and I. Roger, Biochim. Biophys. Acta, 106, 638 (1965). 